DOI: $10.17516 / 1997-1370-0539$

УДК 343.81: 341.491

\title{
Optimization Principles of Penal Execution System of Russia in the Context of European Penitentiary Practice
}

\author{
Pavel V. Teplyashin \\ Siberian Federal University \\ Krasnoyarsk, Russian Federation
}

Received 02.10.2019, received in revised form 30.12.2019, accepted 11.01.2020

\begin{abstract}
Russia's accession to the European Council and ratification of the European Convention on Human Rights caused considerable improvement of detainees' living conditions. However, at present these transformations are inert and unstable. The framework for the development of the penitentiary system of the Russian Federation for the period until 2020 in terms of the study and dissemination of foreign experience in the area of execution of penalties is the subject-matter of research. The dissemination of this experience however can prove both progressive and regressive meaning for the optimization of domestic penitentiary system.

The use of the method of legal-comparative studies, stressing the importance of the European example in execution of penalties, gives the opportunity to add some principles to the domestic penitentiary system, and among them: reciprocity of mutual interests of personality, society and state; feasibility to use foreign penitentiary experience; consistency that makes it possible to avoid conflicting between national and international law from the point of view of social economic facilities to realize humanitarian standards; the systematic issue as one of the capacity to suppose a clearly defined time sequence of publication and implementation of penitentiary norms. In the light of these principles the penitentiary policy of the Russian Federation is being criticized. Among applications of detainees to the European Court on Human Rights there is a tendency to increase the number of claims of violations of the detainees' constitutional rights by the established prison security requirements.

The results of this research testify about the possibility to use them while reviewing domestic conceptual framework of prison security which continues to express punitive claims primarily of the state to the detainee. Provisions of the European penitentiary rules are far from being fully realized in western prison systems, and that is why they are to be interpreted with the utmost care in legislative statements of the penitentiary legislation of Russia. The research is to conclude about the possibility to account on the critical remarks given in the article when working out on the Concept of modernization of the penal execution system (2021-2030).
\end{abstract}

Keywords: European standards, legal interests, penitentiary, international penitentiary law, treatment of detainees, labor of convicts.

(C) Siberian Federal University. All rights reserved

* Corresponding author E-mail address: pavlushat@mail.ru ORCID: 0000-0002-6737-749X 
Research area: criminal law and criminology; penal law.

Citation: Teplyashin, P.V. (2020). Optimization principles of penal execution system of Russia in the context of European penitentiary practice. J. Sib. Fed. Univ. Humanit. Soc. Sci., 13(1), 123-131. DOI: $10.17516 / 1997-1370-0539$

\section{Introduction}

Before the Concept of development of the penal execution system of the Russian Federation has been adopted for the period until 2020 (hereinafter referred to as the Concept), there was a romantic notion about European traditions and experience of the execution of criminal penalties. The Concept postulates that increasing contacts with penitentiary systems of foreign countries, international non-government organisations, research, educational and scientific centres of the United Nations, Council of Europe, European Union, the States Members of the Commonwealth of Independent States and countries further afield supposes study and dissemination of the foreign example in the sphere of the penal execution and detention.

However, this provision is of a declarative nature, and it is obvious that foreign example in the sphere of the penal execution and detention can be of various nature, and accordingly its 'dissemination' is can have both positive and negative meanings for the optimisation of the domestic penal execution system. This statement is based on the fact that the provision under review is found in the document which is the cornerstone of the penal execution policy of the Russian Federation, and it explains special requirements for all the legal regulations. Government regulations contained in the Concept mean critical path activities, forms and methods of improvement and development of the penal execution system, its link with state organs and institutions of civil society, which provides functioning of the penal execution system for the period until 2020. Exactly, it is this system of helping to solve the issues presented in the second chapter of this document that expresses the essence of the Concept. Accordingly, all the provisions of the document express the leading idea of optimisation of the penal execution system and depict the chosen variant of the execution of criminal punishment in complex. Consequently, further provisions of the Concept must develop and express the formulated points. Moreover, these provisions materialise the sense of build-in system of directives pointed to attain the stated purposes and to solve the tasks formulated in the Concept.

It is important to maintain the idea of V.G. Shevelyov that "the priority areas for reforming are put in the main principles that underlie the process. These principles depict the notions of humanity, human dignity, social orientation and effective management and they are determining factors for the effective functioning of modern penitentiary system" (Shevelev, 2018: 23). Exactly, these principles form the sustainability of legal provisions contained in conceptual documents, which define vectors of the penal execution policy. To follow this, the positive quality of the existing penal execution policy defines establishment and development in the penal execution legislation, in judicial and other law enforcement practices of the constitutional principles, rules and norms of the international penitentiary law and positive example of appellation of detainees in foreign (first and foremost European) countries. Moreover, implementation of actual liberal reform of the penal execution legislation demands its exact matching with the penal execution policy. We know that liberalism in the sphere of detainee treatment is in many ways the result of the influence of European penitentiary ideology. This statement is strengthened by retrospective tendencies of functioning of the domestic penitentiary system studies, in which O.N. Yakovleva and O.I. Malchuk point out that when the system of places for detention was transferred from the Ministry of Internal Affairs to the jurisdiction of the Ministry of Justice of the Russian Empire, the reformers relied the Western European experience (Yakovleva, Malchuk, 2017: 11). A.V. Bykov notes in turn 
that "through the Ministry of Justice and the Central Prison Administration the government did not only try to show its commitment to advanced achievements of the Western European penitentiary science, one of the first priority was to join Russia to the international penitentiary community" (Bykov, 2015: 29).

In modern history the Russia's accession to the Council of Europe and the subsequent ratification of the European Convention on Human Rights and major freedoms in 1950 (hereinafter referred to as Convention) resulted in considerable reformation for treatment of convicts and detainees and transferring of the penal execution system from the Ministry of Internal Affairs of the Russian Federation to the Ministry of Justice of the Russian Federation. Later on the intended movement of the penal execution system and legislation has become inert and unstable. After the existence of the Concept for five years, it was decided not to increase the efficiency of penal execution institutions and agencies executing punishment up to the level of European treatment standards and to transfer to rather abstract development of the activity of penal execution institutions and agencies executing punishment, but to take international standards into account. In any case the International Law and European Law when united, represent the value of the natural legal content of law. In particular, A. Ashworth points out that "unified European Law possesses greater legal force than national law.... The reason of it is the consequence that the International Criminal court was created precisely to fulfill this right and on the basis of observance of Human Rights" (Ashworth, 1999: 63).

\section{Statement of the problem}

Comparative legal analyses of European penitentiary systems gives an opportunity to expand the domestic penal execution policy with a number of interpreted principles: 1) synchronisation of the existing penal execution legislation with the natural and inalienable rights, freedoms and legal interests of a convict when they are directly or implicitly set out in penal execution norms; 2) taking into account the interests of both person, society and state; 3) feasibility excluding the priority of any po- litical purposes and pre-completion legal conformity; 4) systematic process which provides clearly defined time sequence of publication and realization of both material and procedural norms in the sphere of treatment of convicts; 5) relevance of the legal force of legal acts and by-laws; 6) consistency that avoids duplication and contradictions between national and international law from the point of view of social economic opportunities to implement corresponding standards.

The Concept provides analysis of denoted principles and shows a number of problematic areas that reveal a certain inconsistency and contradiction of penal execution policy. However, we are at first to follow the objective of the Concept to improve the activity of penal execution institutions taking onto account international standards and needs of social development and this objective can hardly be viewed as a purpose for it should be focused on a certain result and not to be an activity. The category "improvement" does not imply accuracy of a certain process and with all this it is making ephemeral the follow-up activity. The term "optimization" is more accurate as it is more precise when we want to show efficiency and commitment for the better result having some values of certain indicators: at the level of the whole penal execution system it may be the total cost for its functioning, at the level of certain directions it may be some extent in reducing a number of convicts detained in the same premises of the correctional institution.

The Concept consolidates that in the labour activity of convicts it is important to work out the question on the exclusion of necessity of labour for those sentenced to imprisonment. According to the Concept of the federal target programme "Development of penal execution system (2017-2025)" "when convicts are forced to productive work it is one of the sanctions to implement penal execution policy of the state". Similar contradictions do not allow to follow a number of above said principles in full size.

\section{Discussion}

As it can be shown in the process of implementation of the domestic penitentiary policy we break the idea of synchronisation of the ex- 
isting penal execution legislation with the natural and inalienable rights, freedoms and legal interests of a convict when they are directly or implicitly set out in penal execution norms. A necessary precondition is not created to form legal timing of labour of convicts, it does not help to decide the most important conceptual questions of productive activity of correctional institutions, employment of convicts and individualisation of labour as the means of rehabilitation. When addressing the labour activity of convicts some questions of creation and development of penitentiary production in Russia stay open, and it demands working through the problems of implementation of subjective rights and legal interests of persons detained in custody.

We think that the subsection "Provision of security regime" does not reflect mutual account of interests of a person, society and state. For example, according to Rule 3 of the Minimal standard rules of the UN concerning treatment of detainees (Mandela Rules) in 2015 penitentiary security does not have "to aggravate sufferings" of persons isolated from the rest of the world. In this subsection of the Concept some points are emphasised - the solution of the issues of detainees' security in terms of how to accommodate convicts in crowded dormitories and approaches to segregation of the convicts, and all this suggests the idea of increasing importance of security interests in contrast with the reduction of the role of security as the means of correction and legal construction provided in Article 82 of the Penal Execution Code of the Russian Federation. Thus, the differentiation of treatment conditions of detainees is expected, and accordingly, the security requirements as well. However, the increasing tendency of applications of the convicts to the European Court on Human Rights (hereinafter referred to as ECHR) on insufficient treatment and accommodation conditions, poor sanitation and health care, violations by the correction institution administration, a number of claims concern the situation when the established security requirements violate a number of constitutional rights of those persons, and what is the most symptomatic, they violate the provisions of the European Convention on the Protection of $\mathrm{Hu}-$ man Rights and Major Freedoms of 1950 - all this is not taken in account. For example, the essence of the decision of the ECHR on July 4, 2013 on the case "Antchugov and Gladkov vs. Russia" (claims No.11157/04 and No.15162/05) comes down to the idea that the fact of staying in the detention cannot be taken into account as the reason provided in Part 3 Article 32 of the Constitution of the Russian Federation for deprivation of convicts of the right to vote. In its turn the ECHR in its decision on the case "Khoroshenko vs. Russia" (claim No. 41418/04) on June 30, 2015, came to the conclusion of inadmissibility of explicit prohibition for a convict sentenced to life imprisonment on strict security terms to have long visits during first 10 years of imprisonment specifying in point 148 that this sanction does not provide equitable balance between the right of the complainant to protect private and family life on the one hand and objectives the state-respondent addresses to, on the other hand, and to the conclusion that the state-respondent abused the latitude within that relationship. The studies of the ECHR practice show its praetorian character of activity expressed in gradual expansion of influence of court decisions on the necessity to correct the national legislation and the domestic one as well. We should share the opinion of a number of authors who criticise the ECHR decision on the problem if the persons suffering heroin addiction have the right to be cured with opioid agonist (Junod et al., 2018: 31-36; Rogan, 2017: 3-9). Thus, the ECHR when referring to Article 3 of the Convention came to the conclusion that Member States of the European Council which refuse to cure the convicts suffering drug addiction with opioid agonist (substitution therapy) are to guarantee that another alternative approach to the treatment of drug addicted convicts will have the same affect (Opioid agonist treatment..., 2018). With all this, the Russian Federation has to optimise the national practice of treatment of drug addicted convicts moving in one of two directions and each of them becomes extremely complicated and ambiguous task including medical, social and legal aspects.

It is necessary to join the opinion of V.A. Utkin who argued that "the subject of the trial of the European court in comparison with pre- 
vious cases became not "the issues of fact", but "the issues of law". In other words, "wake-up call" rang and for the law maker ...it is significant to re-evaluate some principle provisions of the domestic Penal Execution Code in the part of defining the status of convicts and differentiation of the prison security for them (Utkin, 2018: 27-28). In turn G. Cliquennois and S. Snacken, when studying the affect of decisions of the ECHR on the national penitentiary legislation of Member States of the Council of Europe, based their study on the analyses of doctrinal resources and they came to the conclusion that court decisions got greater meaning and influence on the formation of prison securities.....they looked through the attitude to the rights of convicts, legitimacy of enforcement and contributed to improvement of detention conditions and security of detainees .....positive responsibilities imposed on the state gradually lead to changes in legal, administrative, judicial and practical spheres and to adoption of internal national criminal and prison legislation providing effective observance of people's rights isolated from the rest of the world (Cliquennois, Snacken, 2018: 9-11; Cliquennois, Herzog-Evans, 2018: 114-130). The specialists studying the praetorian role of the ECHR in the strengthening of safeguards of observing convicts' rights point out that this judicial body serves with distinction to protect rights and freedoms of those deprived of liberty, this work is of real and effective nature and not of theoretical or illusive one, in observance of the European Convention on Human Rights and major freedoms of 1950 (Díez, 2018: 335361).

We think that not to pay attention to this situation in conceptual perspective is the same as to take a dysfunctional position in the sphere of optimisation of the penal execution policy of the Russian Federation. In that regard, it is required to review the domestic conceptual foundation of security which at present continues to express primarily punitive claims of the state to the person who committed a crime. Moreover, differentiation of treatment conditions for convicts proposed in the Concept to enforce them to fulfill the established rules of prison security as private legal determination is not of a logic character since such an element as "differentiation of treatment conditions for convicts" becomes a part of the security itself in correctional institutions and that is why it cannot be directly aimed to provide the rules of detention. These rules according to Article 82 of the Penal Execution Code of the Russian Federation are implemented in the Rules of Internal Regulations of correctional institutions. Exactly, established regulations of execution and serving a sentence being the cornerstone of the prison security provide different treatment conditions depending on the type of correctional institution appointed by the court, changing of conditions of serving a sentence and not the other way around.

It is important to note that provisions of the Concept which provides "development of penal execution system" do not follow the principle of feasibility since when refusing the primary core direction - absolute "prisonation" of penal execution system - the given document has lost its "conceptuality". Pointing out the essence of this moment V.A. Utkin correctly indicates that "the notion 'development' itself seems to be extremely abstract, indifferent and deprived of any 'energetic' meaning" (Utkin, 2018: 94). Accordingly, general directives of legal prescriptions are blurred, thinking of acquiring new holistic quality by penal execution system and legislation are refined, targeting indicators of "successfulness" of the current act of a declarative character are not detected. For example, one of the tasks of the Concept as a problematic situation on the way when reaching the objectives stated becomes "implementation of separate detention of convicts taking into account the severity of crime and criminological character of a convict". However, in the penal execution legislation there are some norms regulating separate detention of convicts depending on the severity of crime. In particular, in point B Part 1 Article 128 of the Penal Execution Code of the Russian Federation it is said that in colony-settlements people who were convicted for the first time for committing intended crimes of petty or medium gravity are serving sentences in the form of freedom deprivation. However, it is no easy thing to talk about the gravity of a com- 
mitted crime already in the process of serving a sentence when the question of separate detention is being decided. Thus, "the gravity of a committed crime" is a criminal category that is why within the framework of penal enforcement relations its meaning has a "retrograde" and to some extent qualifying character since the correctional effect on a convict is reoriented on the current changes of their personality. Consequently, the "the gravity of a committed crime" category becomes a constituent element of a criminological characteristic of a convict and loses its importance it had in criminal legal relations (first and foremost when punishment was imposed). When separate detention is under decision this criminological characteristic of convicts is integrated in the penal execution law. Thus, according to Part 3 Article 9 of the Penal Execution Code of the Russian Federation measures of correction of convicts, one of which is security, are taken according to the type of punishment, character and level of social danger of a committed crime, personality of convicts and their conduct. In this case, personality is evaluated comprehensively and, the criminological characteristic of this category as well.

According to Part 1 Article 117 of the Penal Execution Code of the Russian Federation when penalties are applied to a convict sentenced to imprisonment the consequences why the crime had been committed and the personality of a convict are to be taken into consideration. With all this, measures include moving of a convict to a cell or a single cell-type premises. Thus, in the Penal Execution Code of the Russian Federation legal measures of separate detention of convicts considering criminological characteristic of a convict have been already included, and the appropriate provision of the Concept has a more "proving" meaning than it contains constitutive resolution.

Compliance of the Concept to the principle of consistency causes criticism; this consistency is disturbed within the framework of the document itself (internal aspect) and when this document is referred to legal regulations (external aspect). Thus, within the framework of internal aspect we can give the following situation as an example. In particular, Chapter
"Social and psychological work with convicts. Upbringing and education of convicts" tells about adaptation of advanced foreign experience of a psycho-diagnostic and psycho-correctional work. However, it is not clear why the importance of this experience is not shown in, for example, Chapter "Labour activity, professional education and professional training of convicts". The application of these measures of correction, in particular, in European penitentiary systems has deep traditions, original ways of overcoming existing problems (Rogge et al., 2014: 230-234). For example, in England and Wales since 1993 competitive process of recruiting of teachers from colleges and universities to provide professional education and professional training for convicts has been applied. In 2003 "Education and professional training of convicts" Fund (OLASS) was founded; since 2012 the system of crediting inmates has been used to give them an opportunity to pay for educational service on the third college paragraph, a part or the total amount can be written off against the above mentioned fund under condition of high results in education. Czerniawski points out that this model of motivation for education, though it is rather expensive for tax payers, certainly contributes to the decrease of recidivism in criminality (Czerniawski, 2016: 205-207).

From the point of view of external aspect, it is important to refer to the following example. Thus, Chapter "Social and psychological work with convicts. Upbringing and education of convicts» outlines "the working out of new approaches to the formation of inmates association taking into account their interest and necessity of this one for inmates themselves, improvement of legal regulations of their activity". However, along with this, conceptual regulations on the basis of the Federal law No. 420 "On amendment to the Criminal Code of the Russian Federation and separate legal acts of the Russian Federation" dated December 7, 2011, Article 111 of the Penal Execution Code of the Russian Federation ("Associations of convicts") is considered to cease to be valid and up till now there are not any constructive improvements in this area. The provision on introduction of methods of mediation concerning 
convicts in turn did not get considerable legal institutionalisation.

Moreover, it is important to point out some gaps when the principle of correlation of legal force of normative and subsidiary legal norms is implemented. Beforehand, it should be stated that in order to define legal force and, accordingly, levels of social importance, contradictory subsidiary legal act is in the first line connected with law. We can say that some provisions of the studied document cause critics from the point of view of both legal techniques and legal content. For example, in Chapter "Observance of rights and legal interest of convicts and of persons in custody" in order to provide rights and legal interests of convicts and of persons in custody legislative regulations of the grounds and order of allowing visits of relatives and other persons using video conferences or resources of information and telecommunication network of Internet are possible taking into consideration the opportunities of penal execution system. However, this formulation is not possible for the doctrinal act which can contain certain legal regulations and has no legal force that can fulfill legal regulation of the certain sphere of social relations.

Finally, there are some problems of implementation in the Concept of the principle of consistency and this is expressed in the existing duplication and contradictions between national and international law from the point of view of social and economic opportunities of implementing appropriate standards. Thus, it is not clear what meaning is put in the following provision: "the penal execution system has kept in many ways the features of old penitentiary system developed for another society. It does not take into consideration the present state of economics, integration of the Russian Federation into international legal area, international standards of inmates' treatment", which is provided in Chapter 1 "General characteristic and modern sate of the execution penal system".
A.A. Demichev underlines that "it is obvious that in economic way Russia is lagging behind some European countries and the problem of financing of the penal execution system is rather difficult" (Demichev, 2016: 28). In the conditions of financial crises and deficit of budgeting to finance perspective investment projects including development of production sector the reality of the existed regulations can be put in doubt.

\section{Conclusion}

The major problem of the conceptual development of the execution legal system in Russia in the light of interpreted principles consists in the necessity to define the major model of domestic penitentiary system (and here we are in the state of search) and only then we can implement appropriate functioning of international standards of convicts' treatment. It is important to summarise that recommendable provisions in the essence, in particular, European penitentiary rules are not implemented in full extent because of differences in social and economic, cultural and mental character of western penitentiary systems (Aebi et al., 2015: 427-443; Parrott, 2015: 148-164) and that is why they should be interpreted in legislative constructions of the execution penal legislation in Russia with the utmost care.

As we see it, the set of critical notes can be taken into account in the process of preparation of the Concept of modernisation of the penal execution system (2021-2030) worked out at present as a political legal document defining major vectors, ideology development and reforming of the execution penal system.

Thus, the given material reveals some problems of conceptualisation of penal execution policy of the Russian Federation and reflects appropriate patterns of European penitentiary ideology and forms scientific preconditions of the further optimisation of the penal execution legislation of Russia.

\section{References}

Aebi, M.F., Linde, A., Delgrande, N. (2015). Is There a Relationship Between Imprisonment and Crime in Western Europe? In European Journal on Criminal Policy and Research, 22, 425-446.

Ashworth, A. (1999). Principles of Criminal Law. New York/Oxford: University Press. 
Bykov, A.V. (2015). Znachenie zarubezhnogo opyta dlia sovershenstvovaniia deiatel'nosti ugolovno-ispolnitel'noi sistemy Rossii [The value of foreign experience to improve the activities of the penitentiary system of Russia]. In Aktual'nyye voprosy obrazovaniia i nauki [Current issues of education and science], 3-4, 28-34.

Cliquennois, G., Herzog-Evans, M. (2018). European monitoring of Belgian and French penal and prison policies. In Crime, Law and Social Change, 70, 113-134. DOI: https://doi.org/10.1007/s10611-017-9722-2

Cliquennois, G., Snacken, S. (2018). European and United Nations monitoring of penal and prison policies as a source of an inverted panopticon? In Crime, Law and Social Change, 70, 1-18. DOI: https://doi. org/10.1007/s10611-017-9716-0

Czerniawski, G. (2016). A race to the bottom - prison education and the English and Welsh policy context. In Journal of Education Policy, 31 (2), 198-212.

Demichev, A.A. (2016). Evropeiskie penitentsiarnye pravila i ikh rol' v ugolovno-ispolnitel'noi politike Rossiiskoi Federatsii [European penitentiary rules and their role in the penal policy of the Russian Federation]. In Penitentsiarnoe pravo: iuridicheskaia teoriia i pravoprimenitel'naia praktika [Penal law: legal theory and law enforcement practice], 2 (8), 25-29.

Díez, J.P.S. (2018). Inmates' rights Caselaw in the European Court of Human Rights. In Revista de Derecho Politico, 102, 333-369.

Junod, V., Wolff, H., Scholten, W., Novet, B., Greifinger, R., Dickson, C., Simon, O. (2018). Methadone versus torture: The perspective of the European court of Human Rights. In Heroin Addiction and Related Clinical Problems, 20 (1), 31-36.

Opioid agonist treatment Guiding principles for legislation and regulations (2018). Available at: https://rm.coe.int/2017-ppg-15-oat-guidingprinciples-final-eng/16808b6d9e (accessed 4 November 2018).

Parrott, L. (2015). Tools of persuasion: the efforts of the Council of Europe and the European Court of Human Rights to reform the Russian pre-trial detention system. In Post-Soviet Affairs, 31 (2), 136-175.

Rogan, M. (2017). Human rights and correctional health policy: A view from Europe. In International Journal of Prisoner Health, 13 (1), 3-9.

Rogge, N., Simper, R., Verschelde, M., Hall, M. (2014). An analysis of managerialism and performance in English and Welsh male prisons. In European Journal of Operational Research, 241, 224-235.

Shevelev, V.G. (2018). Sovremennaia reforma ugolovno-ispolnitel'noi sistemy: predposylki, soderzhanie, perspektivy, problemy [Modern reform of the Criminal-Executory System: background, content, perspectives, problems]. In Iurist Iuga Rossii i Zakavkaz'ia [Lawyer of the South of Russia and Transcaucasia], 1, 20-23.

Utkin, V.A. (2018). Kontseptsiia modernizatsii ugolovno-ispolnitel'noi sistemy: predmet, metodologiia, printsipy [The concept of modernization of a penal correction system: subject, methodology, principles]. In Vestnik Kuzbasskogo instituta [Bulletin of the Kuzbass Institute], 2, 91-100.

Utkin, V.A. (2018). Rezhim lisheniia svobody i pravovoi status osuzhdennykh: mezhdu karoi i bezopasnost'iu [The Mode of Imprisonment and the Legal Status of the Sentenced: between Penalty and Safety]. In Ugolovno-ispolnitel'naia sistema: pravo, ekonomika, upravlenie [Criminal-Executory System: law, economy, management], 4, 26-29.

Yakovleva, O.N., Malchuk, O.I. (2017). Pravovye osnovy peredachi penitentsiarnoi sistemy v vedenie Ministerstva iustitsii Rossiikoi imperii v kontse XIX v. [The legal basis for the transfer the penal system to the jurisdiction of the Ministry of Justice of the Russian Empire at the end of the $19^{\text {th }}$ century]. In Vestnik Tomskogo gosudarstvennogo universiteta. Pravo [Bulletin of Tomsk State University. Right], 25, 11-32. 


\title{
Принципы оптимизации уголовно-исполнительной системы России в контексте европейской пенитенциарной практики
}

\author{
П.В.Тепляшин \\ Сибирский федеральный университет \\ Российская Федерация, Красноярск
}

\begin{abstract}
Аннотация. Вступление России в Совет Европы и ратификация Европейской Конвенции по правам человека привели к значительным преобразованиям условий содержания осужденных. Однако такие преобразования в настоящее время стали носить инертный и нестабильный характер. Предметом исследования выступают положения Концепции развития уголовно-исполнительной системы Российской Федерации до 2020 г. в части изучения и распространения зарубежного опыта в сфере исполнения наказаний. Однако распространение такого опыта способно оказать как положительное (прогрессирующее), так и отрицательное (регрессирующее) значение для оптимизации отечественной уголовно-исполнительной системы.

Использование метода сравнительного правоведения и учет европейского опыта исполнения уголовных наказаний позволяют дополнить отечественную уголовноисполнительную политику рядом принципов, среди которых: взаимный учет интересов личности, общества и государства; целесообразность использования зарубежного пенитенциарного опыта; согласованность, позволяющая избежать противоречий между национальным и международным правом с точки зрения социально-экономических возможностей реализации гуманитарных стандартов; системность, предполагающая четко определенную временную последовательность издания и реализации уголовно-исполнительных норм. Сквозь призму этих принципов критикуется уголовно-исполнительная политика Российской Федерации. Отмечается тенденция роста среди обращений осужденных в Европейский суд по правам человека жалоб на нарушение ряда конституционных прав этих лиц установленными режимными требованиями.

Результаты исследования свидетельствуют о возможности их применения при пересмотре отечественных концептуальных основ режима, который в настоящее время продолжает выражать в первую очередь карательные притязания государства к осужденному лицу. Положения Европейских пенитенциарных правил далеко не в полной мере реализуются в западных тюремных системах, поэтому следует их крайне осторожно интерпретировать в законодательных конструкциях уголовноисполнительного законодательства России. Сделан вывод о возможности учета изложенных в статье критических замечаний при разработке Концепции модернизации уголовно-исполнительной системы (2021-2030 гг.).
\end{abstract}

Ключевые слова: европейские стандарты, законные интересы, исправительное учреждение, международное пенитенциарное право, обращение с заключенными, труд осужденных.

Научная специальность: 12.00.08 - уголовное право и криминология; уголовноисполнительное право. 